\title{
ANALYSIS OF THE EFFECTIVENESS \\ OF ADVERTISING MESSAGES. \\ COMPARISON BY MEDIA, TYPOLOGY, AND SCHEDULE OF ADVERTISEMENTS
}

\section{ANALIZA UČINKOVITOSTI OGLAŠIVAČKIH PORUKA. USPOREDBA PO MEDIJU, TIPOLOGIJI I RASPOREDU OGLASA}

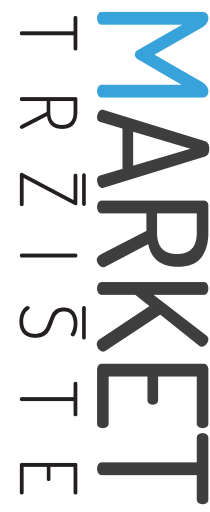

\author{
Market-Tržište \\ Vol. 32, No. 1, 2020, pp. 27-46 \\ UDK 659.11 \\ DOl http://dx.doi.org/10.22598/mt/2020.32.1.27 \\ Original scientific paper
}

\section{Margarita De-Miguel-Guzmán ${ }^{a}$, Carlos Ronquillo-Bolaños ${ }^{b}$, Alexander Sánchez-Rodríguezc, Gelmar García-Vidald ${ }^{\mathrm{d}}$, Reyner Pérez-Campdesuñere, Rodobaldo Martínez-Vivar ${ }^{\mathrm{f}}$}

a Universidad Regional Autónoma de los Andes UNIANDES, Faculty of Business Management, Ave. La Lorena, 230103, Santo Domingo, ECUADOR, e-mail: us.margaritademiguel@uniandes.edu.ec

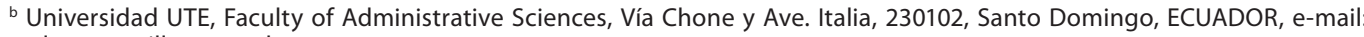
carlos.ronquillo@ute.edu.ec

c Universidad UTE, Faculty of Administrative Sciences, Vía Chone y Ave. Italia, 230102, Santo Domingo, ECUADOR, e-mail: alexander.sanchez@ute.edu.ec

d Universidad UTE, Faculty of Administrative Sciences, Vía Chone y Ave. Italia, 230102, Santo Domingo, ECUADOR, e-mail: gelmar.garcia@ute.edu.ec

e Universidad UTE, Faculty of Administrative Sciences, Vía Chone y Ave. Italia, 230102, Santo Domingo, ECUADOR, e-mail: reyner.perez@ute.edu.ec

f Universidad UTE, Faculty of Administrative Sciences, Vía Chone y Ave. Italia, 230102, Santo Domingo, ECUADOR, e-mail: rodobaldo.martinez@ute.edu.ec

\begin{abstract}
Purpose - This research aims to evaluate how the effectiveness of advertisements can vary according to three fundamental variables: the time schedule of message receipt, the media, and the type of advertising message used.

Design/methodology/approach - An experiment with 375 university students related to administrative careers was devised, creating 25 work groups that were stimulated by multiple advertisements with different combinations of the described variables. Subsequently, various techniques were applied to evaluate the ads used.
\end{abstract}

\section{Sažetak}

Svrha - Cilj je istraživanja procijeniti kako se učinkovitost oglasa može razlikovati ovisno o trima ključnim varijablama, to jest o vremenskom rasporedu primanja poruke, mediju i vrsti korištene oglašivačke poruke.

Metodološki pristup - Osmišljen je eksperiment u kojem je sudjelovalo 375 studenata poslovnog usmjerenja, a oformljeno je 25 radnih grupa koje su poticane višestrukim oglasima s različitim kombinacijama opisanih varijabli. Potom su primijenjene različite tehnike za procjenu korištenih oglasa. 
Findings and implications - The main results showed that advertisements with musical messages have a greater capacity to be retained in the minds of their recipients; similarly, advertising messages that are transmitted through the use of audiovisual media have a greater capacity to please or attract.

Limitation - The main limitation is associated primarily with the characteristics of the sample, as it is a very specific audience, where the influence of other demographic variables, including age, sex, marital status, and living conditions, was not considered.

Originality - The results obtained confirm the contributions of previous studies and reveal patterns of behavior related to the impact of the media and the type of advertisement that is used in its potential to stimulate memories in the subjects receiving the message and to please the target audience, fundamentally in the messages aimed at young audiences (university students). In addition, it provides information on how some attributes that distinguish the advertisement, according to the type of advertising messages used, should be considered as an additional criterion for managers to decide on the type of the advertising message, the fair amount to use, and the most beneficial transmission schedule of such advertisements.

Keywords - advertisement, advertising messages, advertising media
Rezultati i implikacije - Glavni rezultati pokazali su da oglasi s glazbenim porukama imaju veću sposobnost zadržavanja u svijesti primatelja poruke kao i da oglašivačke poruke koje se prenose korištenjem audiovizualnih medija imaju veći kapacitet za ugoditi ili privući.

Ograničenja - Glavno ograničenje uglavnom je povezano s karakteristikama uzorka jer je riječ o vrlo specifičnoj populaciji u kojoj utjecaj drugih demografskih varijabli, poput dobi, spola, bračnog statusa, životnih uvjeta, između ostalog, nije razmatran.

Doprinos - Dobiveni rezultati potvrđuju doprinose prethodnih istraživanja i otkrivaju obrasce ponašanja povezane s utjecajem medija i vrste korištenog oglasa u odnosu na potencijal poticanja sjećanja u primatelja poruke i ugađanje ciljnoj publici, u osnovi u porukama namijenjenim mladoj publici (studentima). Dodatno, pružaju informacije o tome kako neke atribute, po kojima se oglas razlikuje prema vrsti korištene oglašivačke poruke, treba razmatrati kao dodatni kriterij pri odlučivanju menadžera o vrsti oglašivačke poruke, primjerenoj količini korištenja kao i najpovoljnijem rasporedu prenošenja takvih oglasa.

Ključne riječi - oglas, oglašivačke poruke, oglašivački mediji 


\section{INTRODUCTION}

The advertising campaigns are as old as commerce itself and have only changed with regard to the means and the ways to implement them. Oral advertising, known as "proclamation", was used since ancient times. Also, some campaigns of written publicity are known from the antiquity; writings on tablets found in Babylon for a merchant of ointments, a scribe, and a shoemaker dating back to 3000 BC, or an Egyptian papyrus found in Thebes were the first advertising text. With the appearance of Gutenberg's printing press, advertising writings became more common, at first through the appearance of almanacs interspersed with advertisements, a practice that has reached our days (Eguizábal Maza, 2011).

As the media developed, advertising has been incorporated into all of them: the radio, the cinema, the television, and the Internet. Just as the evolution of these has been rapid, the way of making advertisements has increased in quality and quantity. Perhaps motivated by this development was the appearance in 1930s of the first theoretical postulates of this discipline through the proposals of David Ogilvy (Roman, 2010). This discipline demands the concurrence of several sciences, including psychology, sociology, administration, and economics.

Currently, there is a variety of research carried out in the field of advertising (Diez-Arroyo, 2018; Trastoy-Quintela, Freire-Roucob, RodríguezGonzáleza, Campos Varela \& Rodríguez-Núñez, 2018; Zashchirinskaia \& Nikolaeva, 2018; Kelly, 2019), as well as a large number of ways used to develop advertising by each of the media (Sánchez \& Viejo, 2018; Martins, Costa, Oliveira, Gonçalves \& Branco, 2019). However, not all are equally effective with respect to the objectives they pursue and depending on the medium used or the market segment towards which they are oriented.

The objectives of advertisements do not always directly address an increase in sales, but rather seek to reinforce the value of the brand, the presence in the minds of consumers, the ability to recognize the brand, among other objectives. Similarly, the ways of making the ads alternate different styles or methods, such as: humorous, employment of personalities, fantasy, the values of social groups, opinion leaders or technical expertise, among other forms (Chou \& Wang, 2016; Wiznia, Wang, Steuer \& Elbuluk, 2018).

The purpose of this research is to assess how the effectiveness of messages can vary depending on three fundamental variables: the time a message is received, the media and the type of message used. Therefore, the following scientific question to which this research intended to answer was formulated: Do the parameters such as the time schedule of exposure, the media and the type of advertising message used influence the effectiveness of the advertisements?

\section{REVIEW OF THE LITERATURE}

As already commented, despite the antiquity of advertising as a social and business practice, the amount of research and publications on this subject available in scientific databases show a growing trend over the years (Figure 1), which translates into a manifestation of the relevance of the research topic.

FIGURE 1: Increase in Scopus publications on advertising

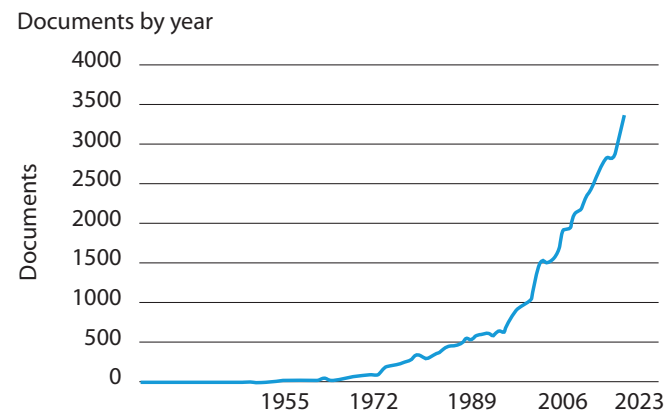

Source: www.scopus.com

In an analysis of 1000 abstracts of more recent scientific papers on this subject matter using

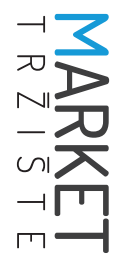


Vosviewer program, two fundamental groups in which these investigations can be grouped could be distinguished (Figure 2). The first contains the generalities of the marketing variables and their benefits for business organizations: price, sales, distribution channels, profits while the other is mainly oriented to more specific aspects related to advertising messages: their design, means used, reaction of consumers, among other aspects. Specifically, this research aims to contribute to the second group analyzed, when trying to study the relationship between the media used and the effects generated in consumers, mediated by other variables that are added to the study.

Research on the subject is dispersed in different geographical areas (Lin, Paragas, Goh \& Bautista, 2016; Mathews-Hunt, 2016; Oglezneva, Petrova \& Ying, 2016; Stanford, 2017; Vilaro, Barnett, Watson, Merten \& Mathews, 2017), evidencing and exemplifying the presence of this type of research on the five continents. Thus, the range of publicity products on which research is carried out is extended, and they are oriented on the scenarios as diverse as tourism and transport (Abayi \& Khoshtinat, 2016; Diez-Arroyo, 2018). In this sense, it should be noted that the products with more advertising studies found were those associated with food (Bugge, 2016), medicines (Sinha, Kesselheim \& Darrow, 2018), and especially on the topics associated with the consumption of substances harmful to the body, such as alcohol, tobacco, or drugs (Martino et al., 2016).

Similarly, there are results available of comparative analyses of the effects of advertising on the basis of independent variables, including gender (Wyllie, Carlson \& Rosenberger, 2015; Lancellotti \& Thomas, 2018), ethnic differences (Lau \& Lee, 2018; Strebinger, Gao, Klauser \& Grant-Hay, 2018), and age. In this last variable, one should note a predominance of research related to the advertising focused primarily on the market segment of youth (Bugge, 2016; Krugman, 2016), and children (Trastoy-Quintela et al., 2018; Zashchirinskaia \& Nikolaeva, 2018; Kelly, 2019).

There is another wide range of advertising research that delves into more specific aspects, such as: the influence of culture on the effects of advertising (Kubat \& Swaminathan, 2015; Margariti, Boutsouki, Hatzithomas \& Zotos, 2018); ethical values and their relationship to advertising (Mpinganjira \& Maduku, 2019); the expenses and the budget for advertising (Gijsenberg \& Nijs, 2018); the relationship with the price (Anderson, Baik \& Larson, 2015; Esteves \& Resende, 2019); the effect of legal regulations on advertising (Greiner \& Sahm, 2018); the influence of time (Hsu \& Chen, 2018), previous experiences (Kim \& Bruce, 2018), and temperature (Bruno, Melnyk \& Völckner, 2017).

FIGURE 2: Analysis of the relationship of the terms used in the publications on advertisements

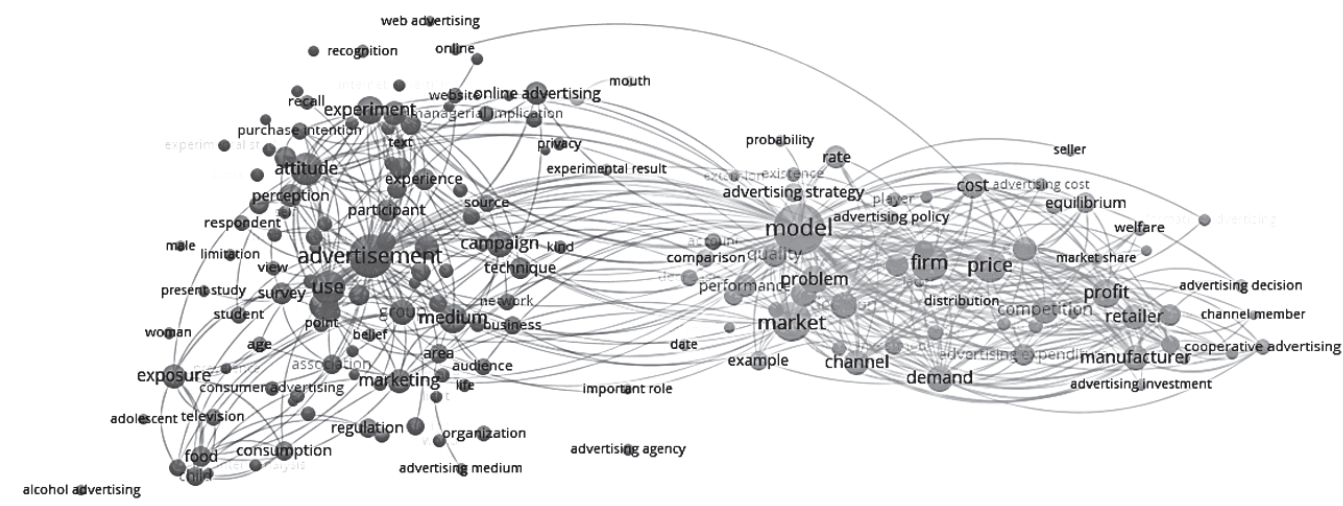

Source: Vosviewer Program 
Despite the great diversity of research on advertising, it can be argued that in one way or another most of these studies analyze four basic aspects: the media used, the type of advertising message, the characteristics of the public to whom it is addressed, and the impact that is achieved with it. In line with the above, there is also a wide spectrum of methods, techniques, and tools used to study the subject. In this sense, the use of statistical techniques, postulates of fuzzy logic, genetic algorithms, or neuro marketing tools (Hajarian, Bastanfard, Mohammadzadeh \& Khalilian, 2017) has been noted.

When it comes to the elements of advertising such as the selected media or the type of advertising message used, several investigations stand out. According to the media, relevant studies focused on the messages developed for the radio (Martín-Santana, Muela-Molina, Reinares-Lara \& Rodríguez-Guerra, 2015; Martín-Santana, Muela-Molina, Reinares-Lara \& Rodríguez-Guerra, 2017); the written press (El-Toukhy \& Choi, 2016; Wiznia et al., 2018); television and outdoor advertising (Dulebenets, Ozguven \& Moses, 2018); advertising on mobile devices (Enwereuzor, 2017); and, as expected in accordance with the evolu- tion of technological trends, there is an increase in the study of Internet advertising (Sánchez \& Viejo 2018) and social networks as part of it (Lee \& Hong 2016), or of the use of smartphones (Muk \& Chung, 2015; Martins et al., 2019).

Regarding the type of advertising message, although not all options have been exhausted, there are studies on different types of advertisements, including those with humorous elements (Oikarinen \& Söderlund, 2016) or featuring happiness or sex as a central message (Wyllie et al., 2015; Chou \& Wang, 2016). We also observed the existence of research that deepens the positive or negative impact or attributes of advertising, such as honesty, attractiveness, or certainty of the scientific benefits that are intended to be transmitted (Kopalle \& Lehmann, 2015; Mansfield-Devine, 2015; Eisenberg, Avery \& Cantor, 2017).

The classification employed for the types of advertising messages to use varies from one author to another, although they usually have several contact points. Table 1 summarizes the classification of the types of advertising messages to be used by four of the most cited authors on this subject (Kotler \& Armstrong, 2013;

TABLE 1: Variants of classification of types of advertising messages used

\begin{tabular}{|c|c|c|c|}
\hline $\begin{array}{c}\text { Kotler \& Armstrong } \\
\text { (2013) }\end{array}$ & $\begin{array}{l}\text { Bassat } \\
(2002) \\
\end{array}$ & \begin{tabular}{|c} 
Lamb, Hair \& McDaniel \\
(2011)
\end{tabular} & $\begin{array}{c}\text { Clow \& Baack } \\
(2010)\end{array}$ \\
\hline $\begin{array}{l}\text { lifestyles } \\
\text { slices of life }\end{array}$ & $\begin{array}{l}\text { pieces of life } \\
\text { pieces of cinema }\end{array}$ & $\begin{array}{l}\text { daily life } \\
\text { lifestyles }\end{array}$ & \\
\hline personality symbol & $\begin{array}{l}\text { the presenter } \\
\text { testimonial }\end{array}$ & testimony or spokesperson & \\
\hline $\begin{array}{l}\text { technical } \\
\text { scientific evidence } \\
\text { testimonial evidence }\end{array}$ & $\begin{array}{l}\text { problem } \\
\text { solution } \\
\text { demonstration } \\
\text { comparison } \\
\text { analogy }\end{array}$ & scientific & rationality \\
\hline musical & musical & musical & musical \\
\hline fantasies & visual symbol & fantasy & sex \\
\hline moods & & $\begin{array}{l}\text { humorous } \\
\text { product symbols } \\
\text { mood }\end{array}$ & \begin{tabular}{|l} 
fear \\
humor \\
emotions \\
shortage
\end{tabular} \\
\hline
\end{tabular}


Bassat, 2002; Lamb, Hair \& McDaniel, 2011; Clow \& Baack, 2010).

According to the authors consulted (Table 1) among the scientific literature available on the subject, the types of advertising messages used condition the results achieved. For example, for Clow and Baack (2010), "... A rational advertisement produces a stronger conviction about the benefits of the product, so that the purchase is finally made. A rational resource is superior to others in terms of developing or changing attitudes and establishing beliefs about the brand...," while Kotler and Keller (2012) point out that what "... is important is the credibility of the spokesperson. The three sources that are most frequently identified are experience, reliability and sympathy. Experience is the specialized knowledge that the communicator possesses to support the claim. Reliability describes how objective and honest the source seems to be...".

Clow and Baack (2010) state that "... musical memories are often stored in the long-term memory areas of the brain. Most people remember childhood songs. Music attracts attention and increases information retention, since it is strongly intertwined with the product. Even if consumers don't remember the argument of the ad message, music can produce a better memory of the visual and emotional aspects of the ad...."

Keller (2008) points out that "... the role played by advertising melodies is more valuable in improving brand awareness, as they often repeat its name in smart and fun ways that allow more opportunities for consumers to codify it. It is also likely that people mentally review or repeat the sticky parts of the melodies after hearing the announcement, which offers more coding opportunities and a greater possibility of memorization...".

According to Clow and Baack (2010), the visual elements of the advertisements are important in emotional resources. In this sense, they claim that "... Television is one of the best means for emotional resources. Television offers advertis- ers intrusion value and uses both sound and sight. Facial expressions convey emotions and attitudes. Television ads are also more vivid, more true to reality and create dynamic situations that attract the viewer to the ad. Most creatives believe that emotional advertising is the key to brand loyalty...". This idea was contributed to by Kotler and Keller (2012), for whom television is recognized as the most powerful advertising medium and the one that reaches a wide spectrum of consumers at a low cost per show. Television advertising has two particularly important strengths. First, you can vividly demonstrate the attributes of the product and persuasively explain the benefits to the consumer. Second, it can dramatically represent the user and usage images, brand personality, and other intangible benefits.

Regarding the radio, Kotler and Keller (2012) point out that "... radio is a very penetrating medium: it is a particularly effective medium during the mornings; it also allows companies to strike a balance between wide and localized market coverage...".

Finally, both Keller (2008) and Clow and Baack (2010) highlight the shortcomings of print ads by stating that they are limited in their reach by the lack of reading habit among young audiences. On the other hand, the static nature of visual images in print media makes it difficult to offer dynamic presentations or demonstrations. Another disadvantage is that it may be too passive. Although advertisers have some flexibility in the design and placement of newspaper advertisements, poor reproduction quality and short service life affect their poor performance.

According to Keller (2008), advertisements should be aimed at strengthening brand awareness. Understanding that brand awareness consists in the recognition and remembrance of the brand. According to this author, brand recognition is the ability of consumers to confirm their prior exposure to the brand, and brand recall is the ability of consumers to recover the brand from memory. 
Despite the great diversity of publicity studies that are available, no research was found that at least explicitly integrated and systematized comparative analyses of the capacity of the advertisements according to the medium used and the type of message, or of the time schedule of message delivery to generate a significant impact on the recall capacity of the target audience, specifically in an audience of young university students.

\section{METHODOLOGY}

The research was carried out through a series of phases during the months of January to June 2019, using a specialized audiovisual classroom of the Faculty of Administrative Sciences of the UTE University as an advertising laboratory for this study and students as participants. Phases III and $V$ were concentrated in the months of April and June. The logic followed for this is shown in Figure 3.

As part of Phase I: Ad Database Creation, a database of advertising messages with diverse characteristics, selected on the Internet, was created. Table 2 summarizes the structure of the formed ad database. As can be seen, written, audiovisual, and sound media are represented in the same proportion in this database. Similarly, five different types of concept of advertising messages were examined; their classification presented by Kotler and Armstrong (2013), according to Table 1, was used by consensus among the authors of this article as it is the most recognized and widely used in the context of this study. The only type of advertisements excluded were those referring to moods because they are used very rarely.

FIGURE 3: Representation of the methodology used in phases

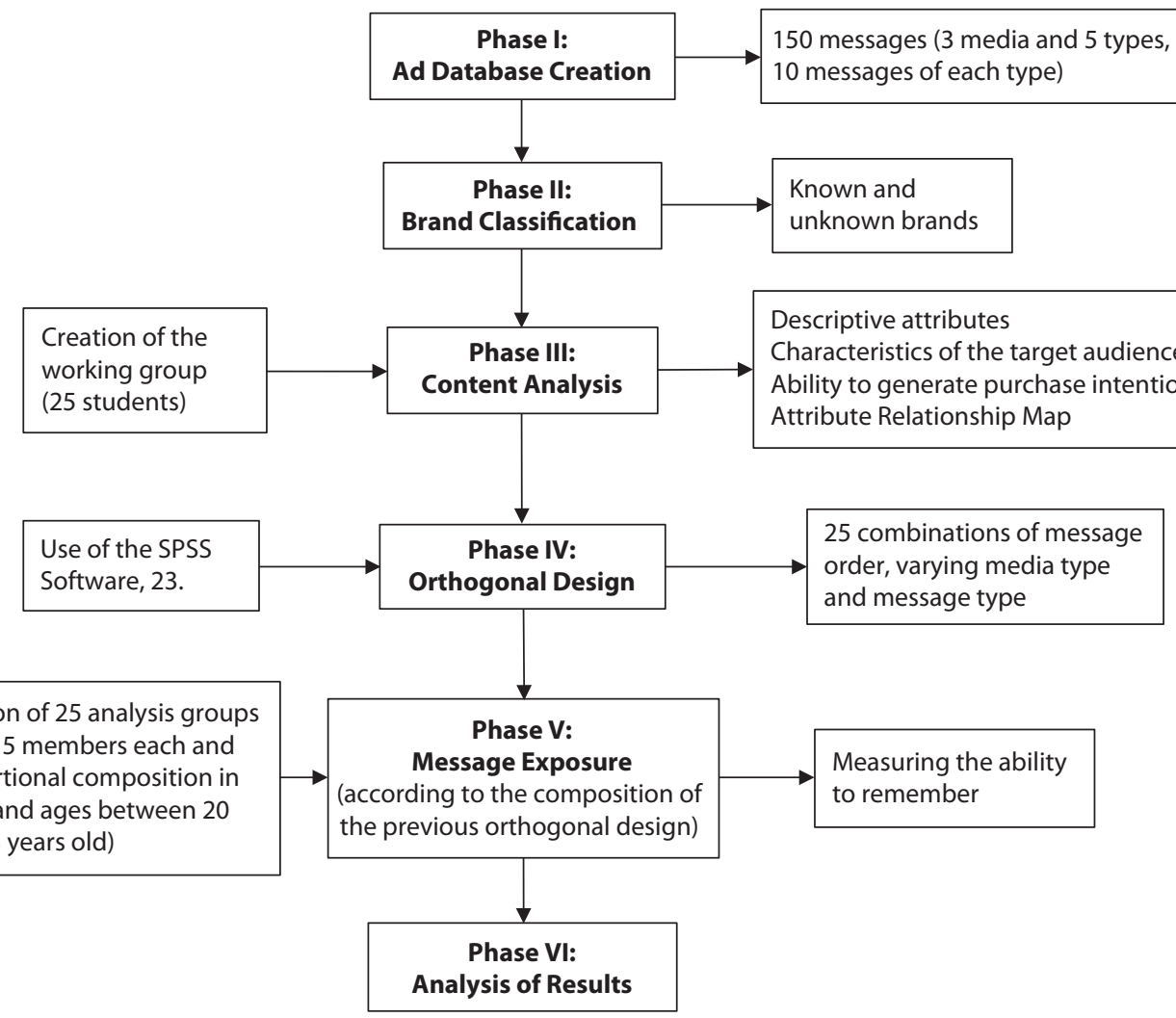


TABLE 2: Summary of the structure of the advertising message database

\begin{tabular}{|l|c|c|c|c|c|c|}
\hline Media type & Lifestyles & Fantasies & Musical & $\begin{array}{c}\text { Personality } \\
\text { symbol }\end{array}$ & $\begin{array}{c}\text { Technical } \\
\text { expertise }\end{array}$ & Total \\
\hline Audiovisual (TV, video) & 10 & 10 & 10 & 10 & 10 & 50 \\
\hline Sound (radio) & 10 & 10 & 10 & 10 & 10 & 50 \\
\hline $\begin{array}{l}\text { Still image (press, } \\
\text { billboards) }\end{array}$ & 10 & 10 & 10 & 10 & 10 & 50 \\
\hline Total & 30 & 30 & 30 & 30 & 30 & 150 \\
\hline
\end{tabular}

Phase II: Brand Classification followed and, as a policy for the formation of the ad bank, it was established that $50 \%$ of the advertisements should be of known brands (more than 5 years of commercialization, international reach, high frequency of ads) and the other $50 \%$ of less known brands (less than 5 years of commercialization, national reach, low frequency of ads).

In the advertising messages considered, 75 different types of products were contemplated, as outlined below (Table 3).

TABLE 3: List of products included in the study

\begin{tabular}{|c|c|c|}
\hline Airlines & Facial cleansing products & Nutraceutical foods \\
\hline Animal proteins & Facial protection products & Painting \\
\hline Banking services & Fast food & Peanuts \\
\hline Beer & Financial entity & Pizza \\
\hline Bread & Formal wear & Pubs \\
\hline Candies & Fungicide & Refreshments \\
\hline Car & Furniture for home & Rehydrating beverages \\
\hline Casual clothes & Hair dye & Sanitary towels \\
\hline Casual shoes & Handbags & Seasoning \\
\hline Casual cakes & Hardware & Shampoo \\
\hline Cereal & Household appliances & Shower gel \\
\hline Chocolate & Humanitarian medical service & Smart phone \\
\hline Chocolate covered cookies & Ice cream & Snacks \\
\hline Chocolate nougat & Intimate soap & Soda \\
\hline Cider & Jeans & Sports accessories \\
\hline Coffee & Jelly & Sports shoes \\
\hline Conditioner & Juices & Sweets \\
\hline Cosmetics & Liquors & Telecommunications service \\
\hline Deodorants & Mall & Tobacco \\
\hline Digital camera & Medical insurance & Toothpaste \\
\hline Disinfectants & Milk & Travel smartphone app \\
\hline Easter bread & Mineral water & Watches \\
\hline Energizing beverages & Motorcycles & Whiskey \\
\hline English course & Music & Wine \\
\hline Face cleanser & Mustard & Yogurt \\
\hline
\end{tabular}


Similarly, 132 different brands listed in Table 4 were contemplated.

TABLE 4: List brands contemplated in the study

\begin{tabular}{|c|c|c|c|}
\hline AC/DC & Claro & Isenbeck & Powe Ade \\
\hline Acobir Expo Inmobiliaria & Clean Men & Johnnie Walker & Pronaca \\
\hline AdeS & Coca-Cola & Johnson's Baby & Rancheritos \\
\hline Adidas & Comercial Del Sol & Juan Valdez & Ranchero \\
\hline Amstel & Cooler in Cotton & Kekos & Red Bull \\
\hline Antioqueño & Coppel & Kellogg's & Roxy \\
\hline Armani & Covergirl & Kool Aid & Sabritas \\
\hline Avianca & D-Box & Koral & San Marcis \\
\hline Axe & Decameron & Lee & Saviloe \\
\hline Bacardi & Del Valle & Lomecan & Sedal \\
\hline Bamboo Restaurant & Diana & L’Oréal & Seeker Syngenta \\
\hline Banco Ciudad & Doritos & Lux & Skechers \\
\hline Banco Pichincha & EFE & Maluma & Skittles \\
\hline Banco Popular & El Coto Vino & Mantecol & Sony \\
\hline Bilz y Pap & El Gaitero & Mc Cormick & Southfruit \\
\hline Bimbo & Emidio Tucci & Metro Shoes & Speed Max Cero \\
\hline Bonicessote & English Live & Michelin & Suburbia \\
\hline D'Onofrio & Epura & Motel los Cerezos & Suchard \\
\hline Brahma Women & Eucerin & Movistar & Supán de Pascua \\
\hline BreaK-Music & Fábrica de Francia & Naturella & Supermaxi \\
\hline Breitling & Ferrari & Nectar & Tampico \\
\hline Cablevision & Fuxion & Negrita & Tecate \\
\hline Cachantun & Glade & Neutrogena & Totto \\
\hline Cadbury & Golden & Nike & Toyota \\
\hline Caprice & Green & Nivea & Uber \\
\hline Casa Tarradellas & Grefusa & Oral B & Under Armour \\
\hline Beck's & Happy Deck & Pantene & Valencia Liquor \\
\hline Cheetos & Harley Davidson & Papa John's & Absolut Vodka \\
\hline Chevrolet & Herbal Essences & Pato Aflac & Yes \\
\hline Chocolate Mondo & Home Depot & Pecho Frio heladería & Volt \\
\hline Chocolinas & Honda & Pepsi & Worm \\
\hline Cillit Bang & Hoteles.com & Pilsener cero & Zambo \\
\hline Cklass & IPOD & Pony Malta & Zuu \\
\hline
\end{tabular}

As can be seen from the structure of products and brands examined in the study, both were numerous and representative of a large part of the market.
As part of Phase III: Content Analysis, a test study group was formed of only 25 young people (university students in final years of Business Administration, International Business or 


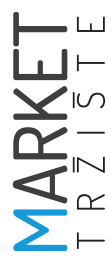

Marketing studies, ranging between 20 and 25 years of age, of whom $22 \%$ were female) for the purpose of analysis of the content of the advertising messages. For this, the members of the group were initially exposed to the selected advertisements and, subsequently, a written questionnaire was used to collect the information from the respondents, each of whom was asked to answer the following questions, prepared based on the proposals of the aforementioned authors:

1. What is significant about your ad?

2. What do you dislike about the ad?

3. If you had to summarize the message in three words, what would they be?

4. With what adjectives would you describe the target audience of the message?

5. If you had the possibility, would you buy this product? (I would buy it; Maybe I would buy it; I do not know if I would buy it; I probably would not buy it; and I would not buy it)

6. Evaluate the following attributes in the ad:

\begin{tabular}{|l|l|l|l|l|l|}
\hline & $\begin{array}{l}\text { Very } \\
\text { high }\end{array}$ & High & Medium & Low & $\begin{array}{c}\text { Very } \\
\text { low }\end{array}$ \\
\hline Attractive & & & & & \\
\hline Quality & & & & & \\
\hline Transcendent & & & & & \\
\hline Stimulating & & & & & \\
\hline Credible & & & & & \\
\hline
\end{tabular}

With questions 1, 2, and 3, the distinctive attributes of the brands were established according to the opinion of the individuals surveyed. The attributes cited by the respondents were classified by the researchers considering the nature or intent of the attribute in seven dimensions or groups: socialization skills, energy, emotional state, intellectual capacity, physical capacity, behavior, and profession or occupation.

Similarly, with question 4 , the characteristics attributed to the proposed target audiences of the messages were identified by the characteristics presented in the advertisement, according to the perception of the subjects under investigation. The same procedure was applied for question 5 , where the capacity of the advertising message was determined to generate a certain level of purchase intention in the target audience. Based on the results of question 6 , a positioning map was made through a correspondence analysis processed in the IBM SPSS 23.

The correspondence analysis allows for a representation of the relationship between the evaluation of each of the attributes received by different messages, and its relationship with the marks that these messages represented. The matrix for the analysis was formed for the 131 brands: the five attributes and their recognition in each of the brands were evaluated. The two dimensions represented on the map must be interpreted and identified by the researchers, considering the scales used and the results obtained.

According to the database of advertisements and possible combinations, based on the types of advertising messages defined, the media to be used and the analysis schedules, the possible number of study groups was found to be 75 ; being very high for the development of the study, it was necessary to perform the orthogonal design, explained in the next phase.

To carry out Phase IV: Orthogonal Design, an orthogonal analysis design matrix was formed for the purpose of randomly selecting the possible combinations through the use of IBM SPSS 23. The method is similar to that used by Anand, Bansal, and Aggrawal (2018) and Speight, Schiano, Harwood, and Drake (2019). In the present study, three dimensions were combined: the order of the type of media used, the order of the type of advertising message, and three possible schedules to be exposed to the effect of the advertisement. In each study group, 10 ads were used, as summarized in Table 5.

The media column indicates the order of the advertising media used, i.e. audiovisual, radio, and print, as they appear in sequence. Similarly, the column with the type of advertising messages outlines the sequence of fantasy, personality 
TABLE 5: Orthogonal design of the experiment

\begin{tabular}{|c|l|l|l|l|l|l|l|}
\hline No & Schedule & \multicolumn{1}{|c|}{ Media } & \multicolumn{1}{|c|}{$\begin{array}{c}\text { Type of } \\
\text { advertising } \\
\text { message }\end{array}$} & No & Schedule & \multicolumn{1}{|c|}{ Media } & \multicolumn{1}{|c|}{$\begin{array}{c}\text { Type of } \\
\text { advertising } \\
\text { message }\end{array}$} \\
\hline 1 & morning & sound & technical expertise & 14 & afternoon & still image & fantasies \\
\hline 2 & morning & still image & musical & 15 & afternoon & audiovisual & technical expertise \\
\hline 3 & morning & audiovisual & musical & 16 & afternoon & audiovisual & lifestyles \\
\hline 4 & morning & still image & personality symbol & 17 & afternoon & still image & technical expertise \\
\hline 5 & morning & still image & lifestyles & 18 & afternoon & sound & lifestyles \\
\hline 6 & morning & audiovisual & lifestyles & 19 & afternoon & audiovisual & personality symbol \\
\hline 7 & morning & sound & fantasies & 20 & afternoon & sound & musical \\
\hline 8 & morning & audiovisual & technical expertise & 21 & night & still image & technical expertise \\
\hline 9 & morning & audiovisual & personality symbol & 22 & night & audiovisual & fantasies \\
\hline 10 & morning & still image & fantasies & 23 & night & sound & personality symbol \\
\hline 11 & afternoon & still image & personality symbol & 24 & night & audiovisual & musical \\
\hline 12 & afternoon & still image & musical & \multirow{2}{*}{25} & night & still image & lifestyles \\
\hline 13 & afternoon & audiovisual & fantasies & & aund & \\
\hline
\end{tabular}

symbol, musical, lifestyle, and technical expertise. As can be seen in Table 5, measurements were made 10 times in the morning, as many times in the afternoon, and only five times at night. The number of times in each schedule corresponded to the results of the orthogonal design.

During Phase V: Message Exposure, work continued with the 25 study groups created with 15 members each, where both sexes were represented in equal proportion. As explained above, they combined university students aged between 20 and 25, pursuing business studies related to administration and marketing. We worked with 375 students in total. In no case were the same students repeated to avoid biases of the accumulated memory.

After the members of each group were exposed to each advertisement, following the order dictated by the orthogonal design, the respondents were subjected to message stimulation in an advertising laboratory of the Faculty. Each of the advertisements was presented consecutively according to the pre-established order for a period of 30 seconds.
The ability to remember the advertising messages was evaluated by applying two types of questions. In the first, assuming they needed one of the products mentioned in the question and that they perceived it in the advertisement, respondents were asked to mention which brand they remembered. In the second, a list of brand names included in the messages was provided to them incompletely, so that, in accordance with the recall, they would complete the brand name. For example:

1) If you were thinking about eating a healthy snack, what brands come to mind?

2) Fill in the name of the following brand: $\mathrm{N}_{-} \mathrm{e}_{-}$

No more than two to five minutes elapsed between the exposure to the advertisements and the application of the questionnaires, guaranteeing that the respondents received no external advertising stimuli by other media during that time interval; they always had their mobile devices (tablets, smartphones, etc.) removed before each work session. 
The questions above were designed according to the recommendations of Keller (2008), formulated for each of the brands evaluated and shown in the messages, and were applied to each of the participants of the groups created. With the information collected a matrix, recording the total number of individuals who received the message, the order in which they received it according to the orthogonal design, and the number of times each advertising message was remembered was formed in SPSS 23. For each message the potential to stimulate memories (PSM) was determined, and the following formula (1) was proposed for that purpose:

$$
P S M=\frac{C_{i r}}{C_{i e}}
$$

where:

$C_{\text {ir: }}$ number of individuals who remember the advertising message;

$C_{i e}$ : number of individuals submitted to the advertising message.
This indicator was analyzed for each advertisement in each of the variants of the orthogonal design. Subsequently, comparisons of the behavior of this indicator were made, in accordance with the selected modality of the orthogonal design, in search of significant differences in the memory of the advertisement according to the media used, the type of advertising message and the time schedule used. A one-factor analysis of variance (ANOVA) was used to evaluate the existence of significant differences.

\section{RESULTS}

As established in Phase VI: Analysis of Results of the methodology, following the content analysis performed according to the criteria of the evaluators, the attributes that allowed defining the target audience to which the advertising messages were directed are summarized as shown in Table 6.

TABLE 6: Summary of attributes that characterize the target audience of advertisements

\begin{tabular}{|c|c|c|c|c|c|c|c|}
\hline Dimensions & \multicolumn{6}{|c|}{$\begin{array}{l}\text { Attributes by dimensions and number of respondents } \\
\text { that recognize it }\end{array}$} & Total \\
\hline \multirow{2}{*}{$\begin{array}{l}\text { Socialization } \\
\text { Skills }\end{array}$} & accessible & friendly & $\begin{array}{l}\text { communi- } \\
\text { cative }\end{array}$ & funny & outgoing & introverted & \multirow[t]{2}{*}{120} \\
\hline & 35 & 41 & 10 & 8 & 18 & 5 & \\
\hline \multirow{2}{*}{ Energy } & active & passionate & busy & dynamic & energetic & & \multirow{2}{*}{157} \\
\hline & 54 & 23 & 10 & 41 & 29 & & \\
\hline \multirow{2}{*}{$\begin{array}{l}\text { Emotional } \\
\text { state }\end{array}$} & cheerful & stimulating & innocent & optimistic & tender & & \multirow{2}{*}{50} \\
\hline & 28 & 2 & 2 & 16 & 2 & & \\
\hline \multirow{2}{*}{$\begin{array}{l}\text { Intellectual } \\
\text { capacity }\end{array}$} & clever & creative & instructed & smart & perceptive & dreamer & \multirow{2}{*}{33} \\
\hline & 12 & 5 & 2 & 3 & 4 & 7 & \\
\hline \multirow{2}{*}{$\begin{array}{l}\text { Physical } \\
\text { capacity }\end{array}$} & attractive & feminine & young & childish & modern & healthy & \multirow{2}{*}{24} \\
\hline & 15 & 2 & 4 & 1 & 1 & 1 & \\
\hline \multirow[t]{2}{*}{ Behavior } & confident & careful & discreet & $\begin{array}{l}\text { responsi- } \\
\text { ble }\end{array}$ & simple & $\begin{array}{l}\text { sophisti- } \\
\text { cated }\end{array}$ & \multirow[t]{2}{*}{66} \\
\hline & 11 & 8 & 4 & 7 & 12 & 18 & \\
\hline \multirow{2}{*}{$\begin{array}{l}\text { Profession or } \\
\text { occupation }\end{array}$} & $\begin{array}{l}\text { agrono- } \\
\text { mist }\end{array}$ & athlete & student & $\begin{array}{c}\text { entrepre- } \\
\text { neur }\end{array}$ & & & \multirow[t]{2}{*}{6} \\
\hline & 1 & 3 & 1 & 1 & & & \\
\hline
\end{tabular}


The attributes captured in accordance with the content of the ads and the perception of the target audience towards which it is directed were grouped into dimensions. According to these, the messages are aimed at people with high socialization skills, such as: friendly, accessible, communicative, funny and outgoing; with high energy levels, such as: active, passionate, dynamic, energetic and busy; with positive emotional states, such as: cheerful and optimistic; with high intellectual capacities, such as: clever, dreamer, creative, smart and perceptive; with certain physical capacities, such as: attractive and young; exhibiting varied behavioral attributes, such as: sophisticated, simple, confident, careful and responsible; and of various occupations, such as: athletes, agronomists, students, or entrepreneurs. Not all attributes and dimensions were identified or perceived equally by most respondents, with the attributes related to energy, socialization skills, and behavior being more recognized than others; those concerning the dimensions of profession, physical capacities, and intellectual capacities were recognized to a much lesser extent.

Table 7 shows the capacity of the analyzed ads to stimulate the purchase decision. As can be seen, $74.67 \%$ of these advertisements (137 advertisements in absolute terms) are capable of stimulating the purchase decision to some extent; meanwhile, less than $9 \%$ of the ads give rise to some type of doubt about the purchase.

An analysis of attribute perception by the subjects who perceived the messages and then used the attributes to describe them allowed establishing the number of times each of the attributes was used. The attributes used by the majority to rate the messages were: simple, clear, stimulating, and comfortable. A wide range of other attributes were also mentioned by the participants, but they exhibited low repetition frequency, such as: absorbing, inspiring, overwhelming, harmonious, risky, clever, homemade, and casual, to name but a few of the attributes cited.

In assessing the negative aspects of the advertisements that may discourage or limit the influence of the message, according to the respondents' criteria, 108 of the advertising messages were not found to have negative aspects, which corresponds to the evaluation of the stimulus to purchase.

However, 42 advertisements had negative ratings in various aspects. The causes that stand out among the negative elements are: lack of creativity of 8 ads, transmission of negative messages aimed at the consumption of tobacco, alcohol, messages with a sexual or sexist character. Ten ads were evaluated to have audio difficulties, such as voice speed or poor music selection, and the same amount to have image difficulties, such as editing problems or incorrect image selection. Finally, eight advertisements presented problems with the complexity of the message transmitted, resulting in their being either too simple or too complex for understanding.

Finally, regarding the content analysis, a positioning study was carried out through correspondence analysis, thanks to which the positioning map shown in Figure 4 could be constructed, showing the interrelation between the attributes (attributes in the figure) mentioned by the participants and the valued brands (Span. marcas in the figure).

TABLE 7: Evaluation of the capacity or potential of the ads to stimulate the purchase decision

\begin{tabular}{|l|c|c|}
\hline $\begin{array}{l}\text { Purchase intention generated } \\
\text { by the advertisement }\end{array}$ & Frequency (\%) & $\begin{array}{c}\text { Accumulated } \\
\text { frequency (\%) }\end{array}$ \\
\hline I would buy it. & 49.33 & 49.33 \\
\hline Maybe I would buy it. & 25.34 & 74.67 \\
\hline I don't know if I would buy it. & 16.66 & 91.33 \\
\hline I would probably not buy it. & 6.00 & 97.33 \\
\hline I wouldn't buy it. & 2.67 & 100.00 \\
\hline
\end{tabular}




\section{FIGURE 4: Positioning map}

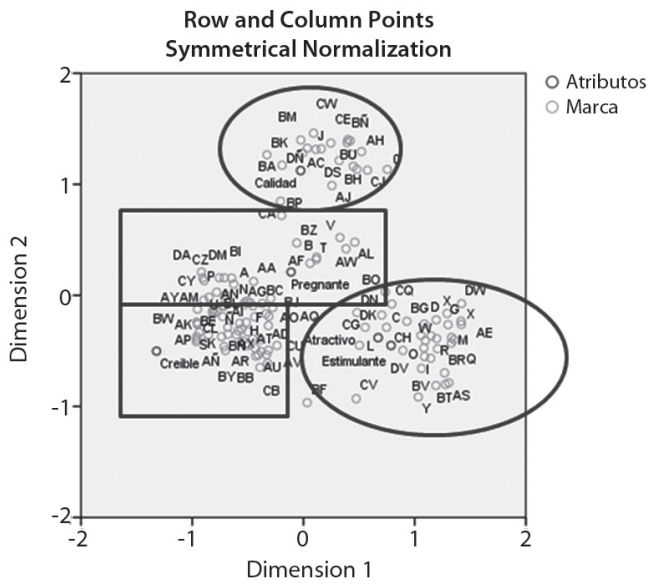

The study was carried out by evaluating the following five attributes in each ad: attractive, quality, stimulating, credible, and transcendent. In the correspondence analysis, the meaning of the dimensions is not considered important because they are the simplified integration in two dimensions of multiple variables, although some researchers usually give it meaning. In this technique, the proximity of the brands to one or the other of the attributes that are evaluated and for which they stand out is more relevant. As can be seen, in general, the brands were distributed around the five attributes. The bestknown brands were highlighted by the quality of the ads, including: Red Bull, Nike, Coca Cola, Pepsi, Ferrari, and Toyota.

On the other hand, ads including a technical concept or personality symbol were recognized as being more credible. Among these brands we can mention: Maluma, Del Valle, Bacardí, and Comercial del Sol. Musical ads of brands such as English Live, AC/DC, Cooler in Cotton, and Break and Music were generally associated with the transcendent attribute. Finally, the attractive and stimulating attributes tended to be placed in a similar position and mainly concentrated around the advertisements that used audiovisual media. Among these were brands such as: Bamboo Restaurant, Acobir, and Supermaxi.
Once the qualitative analysis was completed, quantitative analyses were carried out to assess the influence of the variation of the media, the types of advertising message, and the hours of perception of the messages in their potential to stimulate memories associated with those ads. Each of these results is described below.

\subsection{Influence of the advertising media used on the potential to stimulate memories}

The relationship between both variables is summarized in Table 8. As evidenced, the advertisements broadcast by the audiovisual media showed a greater capacity to stimulate memories than the other two media. To verify the significance of these results, a one-way ANOVA test was applied.

TABLE 8: Relationship between the media used to broadcast the message and the potential to stimulate memories

\begin{tabular}{|l|c|}
\hline Media & PSM \\
\hline Audiovisual & 0.302281 \\
\hline Sound & 0.261591 \\
\hline Still image & 0.245194 \\
\hline
\end{tabular}

Note: PSM = potential to stimulate memories.

As can be seen from the significance obtained in Table 9, the selection of the media can be argued to be decisive for the potential to stimulate memories of the advertisement issued. Among these, those exhibiting the greatest capacity are the audiovisual media, which provide more information to the recipient of the message. The second-ranked among the media was the radio, which can be very attractive thanks to the use of resources such as music or because it is more dynamic than print media; it also has an advantage of producing effects even when the audience is immersed in another activity. 
TABLE 9: ANOVA analysis of the influence of the media on the potential to stimulate memories

\begin{tabular}{|c|c|c|c|c|c|c|c|}
\hline & & & $\begin{array}{l}\text { Sum of } \\
\text { squares }\end{array}$ & df & $\begin{array}{l}\text { Mean } \\
\text { square }\end{array}$ & $\mathbf{F}$ & Sig. \\
\hline \multirow{3}{*}{$\begin{array}{l}\text { CR* } \\
\text { Media }\end{array}$} & Between groups & (Combined) & 0.195 & 2 & 0.097 & 57.147 & 0.000 \\
\hline & \multicolumn{2}{|l|}{ Within groups } & 0.477 & 280 & 0.002 & & \\
\hline & \multicolumn{2}{|l|}{ Total } & 0.671 & 282 & & & \\
\hline
\end{tabular}

\subsection{Influence of the message style on the potential to stimulate memories}

Table 10 shows the relationship evaluated, with the musical ads seen as having the greatest potential to stimulate memories; this could be due to the fact that a young audience (between 20 and 25 years of age) was used for the study. The second type of advertising message that is perceived as having the most effect is the one that uses recognized personalities, such as opinion leaders or influencers followed by young people. The types of advertising messages that show the least potential to stimulate memories are those of lifestyle and fantasy.

As in the previous case, a one-way ANOVA was applied for the verification of the significance of these results. As can be seen in Table 11, according to the significance, it can be stated that the type of advertising message used influences the potential to stimulate memories of the advertisement issued.

TABLE 10: Relationship between the type of advertising message and the potential to stimulate memories

\begin{tabular}{|l|c|c|c|}
\hline $\begin{array}{l}\text { Types of advertising } \\
\text { message }\end{array}$ & Mean & N & Std. Deviation \\
\hline Musical & 0.289689 & 55 & 0.0468773 \\
\hline Personality symbol & 0.288572 & 55 & 0.0682070 \\
\hline Technical expertise & 0.273978 & 47 & 0.0298517 \\
\hline Fantasies & 0.259603 & 60 & 0.0329444 \\
\hline Lifestyle & 0.266286 & 66 & 0.0478058 \\
\hline Total & 0.272269 & 283 & 0.0487914 \\
\hline
\end{tabular}

TABLE 11: ANOVA analysis of the influence of the type of advertising message on the potential to stimulate memories

\begin{tabular}{|l|l|l|c|c|c|c|c|}
\hline \multicolumn{2}{|c|}{} & $\begin{array}{c}\text { Sum of } \\
\text { squares }\end{array}$ & df & $\begin{array}{c}\text { Mean } \\
\text { square }\end{array}$ & F & Sig. \\
\hline \multirow{2}{*}{$\begin{array}{l}\text { SR } \\
\text { Style }\end{array}$} & Between groups & (Combined) & 0.038 & 4 & 0.010 & 4.224 & 0.002 \\
\cline { 2 - 8 } & Within groups & 0.633 & 278 & 0.002 & & \\
\cline { 2 - 8 } & Total & 0.671 & 282 & & & \\
\hline
\end{tabular}




\subsection{Influence of the advertisement exposure time schedule on the potential to stimulate memories}

The relationship between these variables is summarized in Table 12. As can be seen, the morning schedule shows a better coefficient of potential to stimulate memories; conversely, the nighttime is the least significant. This may be due to the feeling of weariness, tiredness, or lack of energy expressed by the target audience used in the investigation. Some of the participants had spent the day working and had classes during the night. This does not differ from the normal course of events in real life because people usually work during the day; however, it is at night that they can consume a lot of advertisements.

The results of the one-factor ANOVA analysis (see Table 13) corroborate the influence of the time schedule in which the advertisement is received on the potential to stimulate memories.

\subsection{Influence of the recognition level of brands on the potential to stimulate memories}

Of all the brands that were analyzed, some including e.g., Adidas, Avianca, Ax, Bacardi, Chevrolet, Claro, Coca-Cola, Decameron, Ferrari, Honda, Johnnie Walker, Juan Valdez, Read, L'Oréal, Lux, Movistar, Nike, Nivea, Pantene, Papa John's, Pepsi, Fishing line, Sony, Totto, Toyota, Uber, and Absolut Vodka, are more known locally, nationally or globally than others. Therefore, we also investigated for the existence of a difference in the potential to stimulate memories, comparing the coefficient of generation of memories for known and unknown brands, whose results are summarized in Table 14 below.

The results of the one-factor ANOVA analysis (see Table 15) corroborate the influence of prior or reinforced brand awareness on the potential to stimulate memories.

TABLE 12: Potential to stimulate memories based on the advertisement exposure time schedule

\begin{tabular}{|l|c|c|c|}
\hline Schedule & Mean & N & Std. Deviation \\
\hline Morning & 0.308377 & 126 & 0.0435907 \\
\hline Afternoon & 0.272531 & 100 & 0.0372198 \\
\hline Night & 0.255727 & 57 & 0.0579197 \\
\hline Total & 0.272269 & 283 & 0.0487914 \\
\hline
\end{tabular}

TABLE 13: ANOVA analysis of the influence of the advertisement exposure time schedule on the potential to stimulate memories

\begin{tabular}{|c|c|c|c|c|c|c|c|}
\hline & & & $\begin{array}{l}\text { Sum of } \\
\text { squares }\end{array}$ & df & $\begin{array}{l}\text { Mean } \\
\text { square }\end{array}$ & $\mathbf{F}$ & Sig. \\
\hline \multirow{3}{*}{$\begin{array}{l}\mathrm{CR} * \\
\text { Schedule }\end{array}$} & Between groups & (Combined) & 0.109 & 2 & 0.054 & 27.078 & 0.000 \\
\hline & \multicolumn{2}{|l|}{ Within groups } & 0.563 & 280 & 0.002 & & \\
\hline & \multicolumn{2}{|l|}{ Total } & 0.671 & 282 & & & \\
\hline
\end{tabular}


TABLE 14: Relationship between brand awareness and the potential to stimulate memories

\begin{tabular}{|l|r|c|c|c|c|c|c|c|}
\hline Brands & N & Mean & $\begin{array}{c}\text { Std. } \\
\text { deviation }\end{array}$ & \multirow{2}{*}{$\begin{array}{c}\text { Std. } \\
\text { error }\end{array}$} & \multicolumn{2}{|c|}{$\begin{array}{c}\text { 95\% Confidence } \\
\text { interval for mean }\end{array}$} & Minimum & Maximum \\
\cline { 3 - 7 } & & & & $\begin{array}{c}\text { Lower } \\
\text { bound }\end{array}$ & $\begin{array}{c}\text { Upper } \\
\text { bound }\end{array}$ & & \\
\hline Known & 50 & 0.2630 & 0.16589 & 0.02346 & 0.2159 & 0.3101 & 0.01 & 0.56 \\
\hline Unknown & 80 & 0.1460 & 0.11134 & 0.01245 & 0.1212 & 0.1708 & 0.01 & 0.46 \\
\hline Total & 130 & 0.1910 & 0.14598 & 0.01280 & 0.1657 & 0.2163 & 0.01 & 0.56 \\
\hline
\end{tabular}

TABLE 15: ANOVA analysis of the influence of brand awareness on the potential to stimulate memories

\begin{tabular}{|l|c|c|c|c|c|}
\hline & Sum of squares & df & Mean square & F & Sig. \\
\hline Between groups & 0.421 & 1 & 0.421 & 23.161 & 0.000 \\
\hline Within groups & 2.328 & 128 & 0.018 & & \\
\hline Total & 2.749 & 129 & & & \\
\hline
\end{tabular}

\section{DISCUSSION, LIMITATIONS AND FURTHER RESEARCH}

The results of this study corroborate the findings of previous research while providing some details that distinguish it. The analysis of the positioning of the brands around the attributes valued in the advertising messages confirmed that the known brands show a greater tendency to be perceived as being of better quality even with the same communicative capacity. That is to say, the brands with the longest residence time, international reach, and with a reported success story tend to be valued more favorably. On the other hand, musical advertising messages were confirmed to have a greater capacity to be retained in the mind of the recipients of the message at least temporarily, that is, they have greater potential to stimulate memories. The foregoing is consistent with the findings of Clow and Baack (2010) and Keller (2008). Likewise, advertising messages that are transmitted through audiovisual media have a greater capacity to please or attract, which is justified by the fact that they can combine more senses in the communication process. They are also the ones with the greatest potential to stimulate memories. In this sense, the results also corre- spond to the criteria formulated by Clow and Baack (2010) and Kotler and Keller (2012). Similarly, the study showed that the type of messages based on technical recommendations or the use of personality symbols tend to be seen as more credible. This result is in line with the arguments of Clow and Baack (2010) and Kotler and Keller (2012).

The position observed in the advertising messages broadcast on the radio and the advantages of the morning schedule coincide with the indications of Kotler and Keller (2012). In addition, the results of previous studies (Keller, 2008; Clow \& Baack, 2010), according to which the effects of print media advertisements on young audiences are limited, were also corroborated; this is probably due to the fact that the habit of consulting this type of media is not widespread among and for its being considered passive media.

Finally, the study allowed establishing the level of incidence that may cause variations, depending on the advertising media used, the type of advertising message, and the time schedule of exposure to the advertisement, in the potential to stimulate memories, specifically in a youth audience university students. Therefore, the initial scientific question can be answered 
by stating that parameters such as the type of advertising message used, the communication media, and the transmission schedule of the ads do influence the effectiveness of these ads.

The results of the research that followed are not entirely conclusive, when applied to a very specific target audience. However, the results achieved offer insights into the patterns of behavior related to the impact of the media on the potential to stimulate memories and please the target audience, as well as into the attributes that are assigned to them, depending on the type of advertising messages used. This can be taken into consideration as an additional criteri- on during managerial decision making on the type of advertising message and media to use, as well as on the time schedule of the transmission of these messages so that they can be more beneficial.

The main limitation of this research lies primarily in the characteristics of the sample on which the study was conducted, as it is a very specific "university students" audience, where the influence of other demographic variables such as age, sex, marital status, or living conditions was not taken into account. In this sense, its very limitations may constitute the outlines to be considered for future research.

\section{References}

1. Abayi, M., \& Khoshtinat, B. (2016). Study of the Impact of Advertising on Online Shopping Tendency for Airline Tickets by Considering Motivational Factors and Emotional Factors. Procedia Economics and Finance, 36, 532-539.

2. Anand, A., Bansal, G., \& Aggrawal, D. (2018). Choice based diffusion model for predicting sales of mobile phones using conjoint analysis. Journal of High Technology Management Research, 29(2), 216-226.

3. Anderson, S., Baik, A., \& Larson, N. (2015). Personalized pricing and advertising: An asymmetric equilibrium analysis. Games and Economic Behavior, 92, 53-73.

4. Bassat, L. (2002). El libro rojo de la publicidad. Ideas que mueven montañas. Barcelona: Random House Mondadori.

5. Bruno, P., Melnyk, V., \& Völckner, F. (2017). Temperature and emotions: Effects of physical temperature on responses to emotional advertising. International Journal of Research in Marketing, 34(1), 302-320.

6. Bugge, A. B. (2016). Food advertising towards children and young people in Norway. Appetite, 98, 12-18.

7. Chou, H-Y., \& Wang, S. S. (2016). The effects of happiness types and happiness congruity on game app advertising and environments. Electronic Commerce Research and Applications, 20, 1-14.

8. Clow, K. E., \& Baack, D. (2010). Publicidad, Promoción y Comunicación Integral en Marketing. $4^{\text {th }}$ ed. Ciudad de México: Pearson.

9. Diez-Arroyo, M. (2018). Metarepresentation and echo in online automobile advertising. Lingua, 201, 1-17.

10. Dulebenets, M. A., Ozguven, E. E., \& Moses R. (2018). The Highway Beautification Act: Towards improving efficiency of the Federal Outdoor Advertising Control Program. Transportation Research Part A: Policy and Practice, 110, 88-106.

11. Eguizábal Maza, R. (2011). Historia de la publicidad. Madrid: Fragua.

12. Eisenberg, M. D., Avery, R. J., \& Cantor, J. H. (2017). Vitamin panacea: Is advertising fueling demand for roducts with uncertain scientific benefit?. Journal of Health Economics, 55, 30-44. 
13. El-Toukhy, S. M., \& Choi, K. (2016). Magazine hyped: Trends in tobacco advertising and readership characteristics, 2010-2014. Preventive Medicine, 91, 132-137.

14. Enwereuzor, I. K. (2017). Capturing consumers' experiences of unsolicited mobile advertising. Telematics and Informatics, 34(7), 948-960.

15. Esteves, R-B., \& Resende, J. (2019). Personalized pricing and advertising: Who are the winners? International Journal of Industrial Organization, 63, 239-282.

16. Gijsenberg, M. J., \& Nijs, V. R. (2019). Advertising spending patterns and competitor impact. International Journal of Research in Marketing, 36(2), 232-250.

17. Greiner, T., \& Sahm, M. (2018). How effective are advertising bans? On the demand for quality in two-sided media markets. Information Economics and Policy, 43, 48-60.

18. Hajarian, M., Bastanfard, A., Mohammadzadeh, J., \& Khalilian, M. (2017). Introducing fuzzy like in social networks and its effects on advertising profits and human behavior. Computers in Human Behavior, 77, 282-293.

19. Hsu, C-C., \& Chen, M-L. (2018). Timing of advertising and the MAX effect. Journal of Behavioral and Experimental Finance, 20, 105-114.

20. Keller, K. L. (2008). Administración estratégica de marca/Branding. $3^{\text {rd }}$ ed. Ciudad de México: Pearson.

21. Kelly, B. (2019). Advertising and Marketing to Children. Encyclopedia of Food Security and Sustainability. Oxford: Elsevier.

22. Kim, H., \& Bruce, N. I. (2018). Should sequels differ from original movies in pre-launch advertising schedule? Lessons from consumers' online search activity. International Journal of Research in Marketing, 35(1), 116-143.

23. Kopalle, P. K., \& Lehmann, D. R. (2015). The Truth Hurts: How Customers May Lose From Honest Advertising. International Journal of Research in Marketing, 32(3), 251-262.

24. Kotler, P., \& Keller, K. (2012). Marketing Management. 14 ${ }^{\text {th }}$ ed. New York, NY: Pearson.

25. Kotler, P., \& Armstrong, G. (2013). Fundamentos de marketing. $21^{\text {st }}$ ed. Ciudad de México: Pearson.

26. Krugman, D. M. (2016). Understanding the Impact That Marketing, Advertising, and Promotion Have on Adolescent e-Cigarette Behavior. Journal of Adolescent Health, 59(6), 609-611.

27. Kubat, U., \& Swaminathan, V. (2015). Crossing the cultural divide through bilingual advertising: The moderating role of brand cultural symbolism. International Journal of Research in Marketing, 32(4), 354-362.

28. Lancellotti, M. P., \& Thomas, S. (2018). Men hate it, women love it: Guilty pleasure advertising messages. Journal of Business Research, 85, 271-280.

29. Lamb, C. W., Hair, J., \& McDaniel, C. (2011). Marketing. $11^{\text {th }}$ ed. Ciudad de México: Cenage Learning.

30. Lau, H. T., \& Lee, R. (2018). Ethnic media advertising effectiveness, influences and implications. Australasian Marketing Journal, 26(3), 216-220.

31. Lee, J., \& Hong, I. B. (2016). Predicting positive user responses to social media advertising: The roles of emotional appeal, informativeness, and creativity. International Journal of Information Management, 36(3), 360-373.

32. Lin, T. T. C., Paragas, F., Goh, D., \& Bautista, J. R. (2016). Developing location-based mobile advertising in Singapore: A socio-technical perspective. Technological Forecasting and Social Change, 103, 334-349.

33. Mansfield-Devine, S. (2015). When advertising turns nasty. Network Security, 11, 5-8.

34. Margariti, K., Boutsouki, C., Hatzithomas, L., \& Zotos, Y. (2018). Visual metaphors in food advertising: A cross-cultural study. Food Research International, 115, 338-351.

35. Martín-Santana, J. D., Muela-Molina, C., Reinares-Lara, E., \& Rodríguez-Guerra, M. (2015). Effectiveness of radio spokesperson's gender, vocal pitch and accent and the use of music in radio advertising. BRQ Business Research Quarterly, 18(3), 143-160. 
36. Martín-Santana, J. D., Muela-Molina, D., Reinares-Lara, E., \& Rodríguez-Guerra, M. (2017). Influence of radio spokesperson gender and vocal pitch on advertising effectiveness: The role of listener gender. Spanish Journal of Marketing - ESIC, 21(1), 63-71.

37. Martino, S. C., Kovalchik, S. A., Collins, R. L., Becker, K. M., Shadel, W. G., \& D'Amico, E. J. (2016). Ecological Momentary Assessment of the Association Between Exposure to Alcohol Advertising and Early Adolescents' Beliefs About Alcohol. Journal of Adolescent Health, 58(1), 85-91.

38. Martins, J., Costa, C., Oliveira, T., Gonçalves, R., \& Branco, F. (2019). How smartphone advertising influences consumers' purchase intention. Journal of Business Research, 94, 378-387.

39. Mathews-Hunt, K. (2016). CookieConsumer: Tracking online behavioural advertising in Australia. Computer Law \& Security Review, 32(1), 55-90.

40. Mpinganjira, M., \& Maduku, D. K. (2019). Ethics of mobile behavioral advertising: Antecedents and outcomes of perceived ethical value of advertised brands. Journal of Business Research, 95, 464-478.

41. Muk, A., \& Chung, C. (2015). Applying the technology acceptance model in a two-country study of SMS advertising. Journal of Business Research, 68(1), 1-6.

42. Oglezneva, E., Petrova, T., \& Ying, J. (2016). Features of Language Communication in a Multicultural Community: Russian Texts of Advertising Signboards in the Border Cities of China. Procedia - Social and Behavioral Sciences, 236, 194-200.

43. Oikarinen, E. L., \& Söderlund, M. (2016). The effects of humour in online recruitment advertising. Australasian Marketing Journal, 24(3), 180-186.

44. Roman, K. (2010). David Ogilvy, el rey de Madison Avenue. Madrid: Gestión.

45. Sánchez, D., \& Viejo, A. (2018). Privacy-preserving and advertising-friendly web surfing. Computer Communications, 130, 113-123.

46. Sinha, M. S., Kesselheim, A. S., \& Darrow, J. J. (2018). Pharmaceutical Advertising in Medical Journals: Revisiting a Long-Standing Relationship. Chest, 153(1), 9-11.

47. Speight, K. C., Schiano, A. N., Harwood, W. S., \& Drake, M. A. (2019). Consumer insights on prepackaged cheddar cheese shreds using focus groups, conjoint analysis, and qualitative multivariate analysis. Journal of Dairy Science, 102(8), 6971-6986.

48. Stanford, N. (2017). Alternative facts and orthodontic advertising in the United Kingdom. American Journal of Orthodontics and Dentofacial Orthopedics, 152(6), 729-730.

49. Strebinger, A., Guo, X., Klauser, F., \& Grant-Hay, P. (2018). Is Multi-Ethnic Advertising a globally viable strategy for a Western luxury car brand? A mixed-method cross-cultural study. Journal of Business Research, 82, 409-416.

50. Trastoy-Quintela, J., Freire-Roucob, J., Rodríguez-Gonzáleza, L., Campos Varela, I., \& Rodríguez-Núñez, A. (2018). Food and drinks advertising directed at children on television during reinforced protection time slot in Spain, 2017. Anales de Pediatría (English Edition), 89(3), 186-187.

51. Vilaro, M. J., Barnett, T. E., Watson, A. M., Merten, J., \& Mathews, A. (2017). Weekday and weekend food advertising varies on children's television in the USA but persuasive techniques and unhealthy items still dominate. Public Health, 142, 22-30.

52. Wiznia, L. E., Wang, J., Steuer, A. B., \& Elbuluk, N. (2018). Deficiency of sun protection advertising exists in consumer magazines across demographic groups and varies by target demographic. Journal of the American Academy of Dermatology, 80(4), 1139-1141.

53. www.scopus.com

54. Wyllie, J., Carlson, J., \& Rosenberger, P. J. (2015). Does sexual-stimuli intensity and sexual self-schema influence female consumers' reactions toward sexualised advertising? An Australian perspective. Australasian Marketing Journal, 23(3), 188-195.

55. Zashchirinskaia, O. V., \& Nikolaeva, E. I. (2018). The perception of advertising images by children of 5 years old. International Journal of Psychophysiology, 131, 151-152. 